\title{
Climate change impacts on snow water availability in the Euphrates-Tigris basin
}

\author{
M. Özdoğan \\ Center for Sustainability and the Global Environment (SAGE) \& Department of Forest and Wildlife Ecology, University of \\ Wisconsin-Madison, 1710 University Avenue, Madison, WI 53726, USA
}

Received: 27 March 2011 - Published in Hydrol. Earth Syst. Sci. Discuss.: 15 April 2011

Revised: 9 August 2011 - Accepted: 3 September 2011 - Published: 8 September 2011

\begin{abstract}
This study investigates the effects of projected climate change on snow water availability in the EuphratesTigris basin using the Variable Infiltration Capacity (VIC) macro scale hydrologic model and a set of regional climatechange outputs from 13 global circulation models (GCMs) forced with two greenhouse gas emission scenarios for two time periods in the 21 st century (2050 and 2090). The hydrologic model produces a reasonable simulation of seasonal and spatial variation in snow cover and associated snow water equivalent (SWE) in the mountainous areas of the basin, although its performance is poorer at marginal snow cover sites. While there is great variation across GCM outputs influencing snow water availability, the majority of models and scenarios suggest a significant decline (between 10 and 60 percent) in available snow water, particularly under the high-impact A2 climate change scenario and later in the 21st century. The changes in SWE are more stable when multimodel ensemble GCM outputs are used to minimize intermodel variability, suggesting a consistent and significant decrease in snow-covered areas and associated water availability in the headwaters of the Euphrates-Tigris basin. Detailed analysis of future climatic conditions point to the combined effects of reduced precipitation and increased temperatures as primary drivers of reduced snowpack. Results also indicate a more rapid decline in snow cover in the lower elevation zones than the higher areas in a changing climate but these findings also contain a larger uncertainty. The simulated changes in snow water availability have important implications for the future of water resources and associated hydropower generation and land-use management and planning in a region already ripe for interstate water conflict. While the changes in the frequency and intensity of snowbearing circulation systems or the interannual variability re-
\end{abstract}

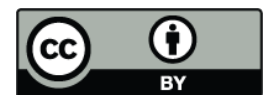

Correspondence to: M. Özdoğan (ozdogan@wisc.edu) lated to climate were not considered, the simulated changes in snow water availability presented here are likely to be indicative of climate change impacts on the water resources of the Euphrates-Tigris basin.

\section{Introduction}

It is widely accepted that projected changes in our climate associated with increasing concentrations of greenhouse gases in the atmosphere will fundamentally alter the magnitude and seasonal variations in temperature and precipitation patterns in many parts of the globe (IPCC, 2007a). What is less known, however, is the impact this change will have on water resources and freshwater ecosystems, especially in mountainous regions where much of the regional water supply is stored as snowpack and glaciers that melt into rivers (Hamlet and Lettenmaier, 1999; Beniston et al., 2003; Mote et al., 2005).

In mountainous ecosystems of the world, seasonal snowpack is a key component of the hydrologic cycle, storing water in winter and releasing it in spring and early summer, when hydroelectric, agricultural, ecological, and recreational demands for water are greatest. In many mountainous river basins, snow is the largest component of water storage but the availability of snow also makes these basins most vulnerable to climatic variations and changes that influence winter snowpack. For example, decline in snow storage due to increased warming, could reduce snowmelt contributions to runoff and the timing of runoff events but not necessarily overall runoff volumes. As a result, too much snowmeltgenerated runoff could occur in early spring, when it is least needed, but this will not help in summer when it is essential for societal and ecological needs. Less snow also means reduced power output in downstream generators, as well as negative impacts to ecosystem functions, including aquatic habitat, fish migration, and wetland replenishment. 
The vulnerability from climatic variations and changes that influence winter snowpack is perhaps best exemplified in the Euphrates-Tigris (E-T) river basin. Aggressive water management programs by Turkey, Syria, and Iraq over the course of the last three decades have resulted in dramatic changes in the land-use patterns and the hydrology of the basin. Most of these changes take the form of capturing snow-generated runoff in a series of dams in the upstream countries and releasing it for irrigation and other economic purposes in the warm season. As a result, these countries now more heavily depend on the continuous existence of seasonal mountain snowpack more than anytime in the history. However, if climate change alters snow-related processes in the mountainous upstream countries, the changes in seasonality and, to a lesser extent, amount of snow accumulation and melting would have important implications for downstream uses such as storage requirements and dam operation. As a result, climate change could have significant implications for evaporative loss, water demand, and agricultural output, as well as long-term hydro-energy planning in the basin (Gleick, 2000). Similarly, continued high population growth in the riparian countries will require sustained (and perhaps increased) levels of snow-generated runoff to maintain the cultural and economical benefits of water use in the basin. Hence climate change, either on its own or when combined with other factors in the long term may provide conditions for conflict between the riparian countries within the E-T watershed.

Several studies have investigated the effects of climate change on winter snow dynamics and associated changes in runoff (Milly et al., 2005). For example, Hamlet and Lettenmaier (1999) used four global climate models (GCMs) to evaluate possible future changes to the Pacific Northwest climate and the surface water response of the Columbia River basin in the US. Their results showed significant increases in winter runoff volumes due to increased winter precipitation and warmer winter temperatures. In particular, the reduced snowpack and earlier snow melt, coupled with higher evapotranspiration in early summer, led to earlier spring peak flows and reduced warm-season runoff volumes. In the same location, McCabe and Wolock (1999) used a conceptual snow accumulation and melt model to estimate future snowpack by using changes in monthly temperature and precipitation simulated by two GCMs. Their results indicated that although winter precipitation is estimated to increase in the future, increases in temperatures will result in large decreases in spring snowpack for the entire western US. Christensen and Lettenmaier (2007) investigated the implications of 21 st century climate change on the hydrology and water resources of the Colorado River Basin using a multi-model ensemble approach with 11 downscaled and bias-corrected global circulation model outputs and a macroscale hydrological model. Their results indicated that modeled April first snow water equivalent (SWE) declined for all ensemble members and time periods. In addition, the maximum reduction (ensem- ble mean) of $38 \%$ for the A2 aggressive climate change scenario occurred later in the century. Associated with decreasing snow water availability and the shift in increased evapotranspiration over the seasonal precipitation, average total basin reservoir storage and average hydropower production generally declined, with a large range across the ensemble. In their more recent work, McCabe and Wolock (2009) simulated mid-spring SWE between 1900 and 2008 in the Western US and concluded that periods of higher-than-average SWE are associated with higher precipitation and lower temperature. While this work focused on past climate conditions, it provides empirical evidence for climate-induced variations in snow pack dynamics that could be affected under future climate change scenarios.

A number of studies also investigated the impacts of climate change in the Middle East and particularly in the E$\mathrm{T}$ basin, although none have concentrated specifically on the effects to snow water availability. Using a super-highresolution GCM, Kitoh et al. (2008), concluded that by the end of this century, the Fertile Crescent (the arc area that covers the headwater region of the E-T basin) will lose its current shape and may disappear altogether, due in part to significant decreases (29-73\%) in the annual discharge of the Euphrates River. Evans (2009) examined the performance and future predictions of $18 \mathrm{GCMs}$ in the Middle East and found an overall temperature increase of almost four degrees $\mathrm{K}$ and a large decrease in precipitation associated with a decrease in storm track activity in parts of Turkey, Syria, and northern Iraq by late 21 st century. Similarly, Önol and Semazzi (2009) assessed the role of global warming in modulating the future climate over the eastern Mediterranean region using a regional climate model under Intergovernmental Panel on Climate Change (IPCC) emission scenarios. Their results suggest a large decrease in precipitation over southeastern Turkey where the headwaters of the E-T basin originate. With these results in mind, the research presented here investigates the effect of projected climatic changes on snow water availability in the E-T basin, using a distributed hydrological model capable of capturing snow-water dynamics in mountainous watersheds. In particular, it focuses on changes in SWE as an aggregate measure of climate change impacts on snow water availability that forms the major source of flow for the twin rivers. Unlike previous research, this study also represents a comprehensive assessment that uses 52 climate change scenario realizations (13 models, two emission scenarios, and two time periods).

\section{Methodology}

\subsection{Study area}

The Euphrates and Tigris Rivers originate from the highlands of eastern Turkey, Iran, and Syria, and discharge south into Syria and Iraq, where they merge to feed the Mesopotamian 


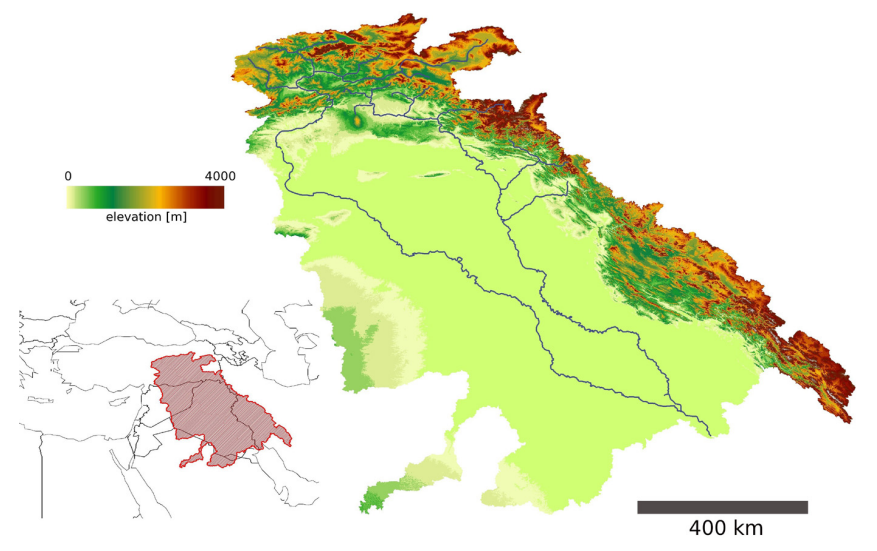

Fig. 1. Location and physiography of the Euphrates-Tigris basin. The location of each river course is also shown. The high elevation zones flanking the north and east of the basin forms the shape of the Fertile Crescent.

marshlands in southern Iraq (Fig. 1). Nearly all of the flow ( $\sim 90 \%)$ of the Euphrates river originates in the highlands of eastern Turkey, with modest contributions from the Syrian highlands but only minimal additions from Iraq (Gruen, 2000). The mountains in eastern Turkey contribute a smaller amount $(\sim 40 \%)$ to the Tigris river flow and the remainder comes from numerous tributaries that originate in the Zagros Mountains between Iraq and Iran (Gruen, 2000). A typical continental climate prevails in the basin, with a distinct north to south temperature and precipitation gradient. Most of the precipitation in the Turkish highlands in the north and in the Zagros mountains in the east occurs between November and April, mostly in the form of snow over higher elevations. At the height of the cold season (February-March), snow cover flanks the northern and eastern edges of the basin, in parallel to the shape of the Fertile Crescent (Fig. 1). Precipitation remains in the snowpack until the spring melt season (MarchJune). Mountain snowpack plays a critical role in the hydrological cycle of the basin, with spring snow-melt being the dominant source for the flow of the two rivers. Hence, annual peak flows in both rivers exhibit a unimodal distribution in which the peak flow coincides with seasonal melting of snow in May independent of in-season precipitation (Fig. 2). Flow steadily decreases throughout the summer and early fall, reaching its lowest value in September-October before the rainy period commences again in November. Given the importance of water for energy production, flood control, agricultural productivity with irrigation, and reservoir operations in the E-T basin, information on water available in the snowpack and the potential changes in the extent, timing, and magnitude of snowpack under a changing climate are crucial.

www.hydrol-earth-syst-sci.net/15/2789/2011/

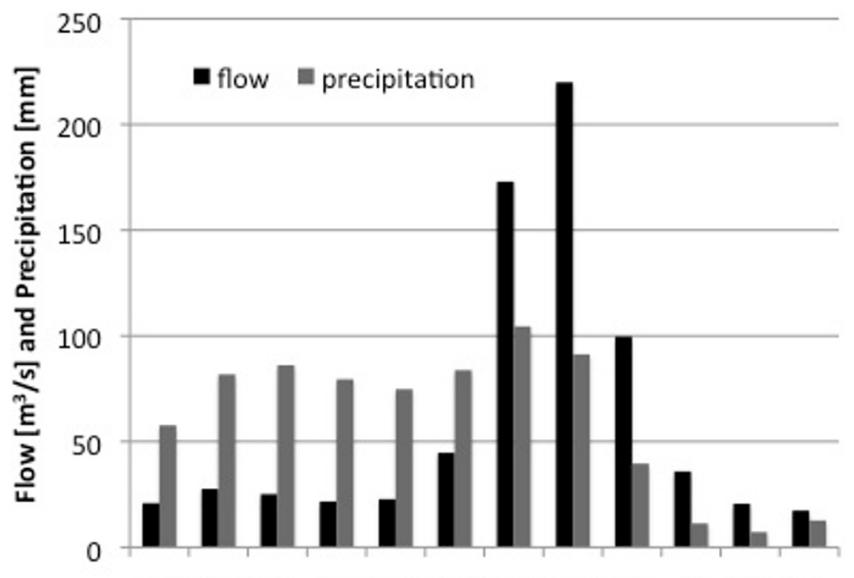

Oct Nov Dec Jan Feb Mar Apr May Jun Jul Aug Sep

Months

Fig. 2. Distribution of long-term averaged Euphrates flow (black) and precipitation (gray) for a location in SE Turkey (centered at $40.16^{\circ} \mathrm{E}$ and $39.6^{\circ} \mathrm{N}$ ). The flow data was obtained from the agency responsible for collecting and disseminating flow data in Turkey (EIEI, 2008). The precipitation data was extracted from the Climatic Research Center (CRU) long-term precipitation climatology dataset (New et al., 2002). Note the start month is October for the water year. The mismatch between precipitation and runoff in the spring is an indication of snow melt-dominated flow in those months.

\subsection{Hydrologic model and meteorological forcing data}

\section{The variable infiltration capacity model}

The Variable Infiltration Capacity (VIC) model is a macroscale hydrology model that has been successfully applied to many continental scale river basins in various climates (Liang et al., 1994; Nijssen et al., 1997; Cherkauer and Lettenmaier, 2003). VIC solves energy and water balance equations over each model grid cell at each time step while distinctly parameterizing subgrid variability in soil moisture, precipitation, topography and vegetation. More specifically, each grid cell can have multiple soil layers and be partially covered by a mosaic of vegetation types and elevation bands. Moisture and energy fluxes are computed separately for each vegetation category and elevation band within each grid cell and then area-weighted and summed over the grid cell. Streamflow is handled by a separate routing subsurface and surface runoff scheme developed by Lohmann et al. (1996).

In VIC cold season processes including snow accumulation and ablation are modeled using a two-layer energy and mass balance model where the thin surface layer is used to solve the energy balance between the atmosphere and snowpack, while the lower layer is used as storage for the excess snow mass (Storck et al., 2002; Cherkauer and Lettenmaier, 2003). Specifically the SWE variable is modeled as 
part of a detailed but straightforward snow module that simulates many of the snow accumulation and ablation processes (Storck et al., 2002). The module is especially well suited for simulating mountain snowpack and includes the effects of forest canopy on snow interception and the attenuation of wind and solar radiation, which are important drivers of snow accumulation, sublimation, and melt processes (Storck, 2000; Storck et al., 2002). Fundamentally, the partitioning between the snow and rain phases of precipitation is determined from a simple scheme based on estimated hourly temperatures that are derived from daily minimum and maximum temperatures. Below $-0.5^{\circ} \mathrm{C}$, precipitation is assumed to fall as $100 \%$ snow and above $0.5^{\circ} \mathrm{C}$ as $100 \%$ rain. A linear relationship between snow and rain is assumed between these two limits. In addition to determining the phase of precipitation, temperature also influences other snow accumulation and melt processes, including convective heat transfer from the air to the snowpack (e.g., Storck, 2000), attenuation of solar radiation and variations in long-wave radiation (determined from the difference between $T_{\max }$ and $T_{\min }$ ), and calculation of the dewpoint and vapor pressure deficit (from minimum temperature) that influence snow sublimation (Thornton and Running, 1999). More specifically, the trends in temperature are indirectly related to trends in longand shortwave radiation, humidity, and vapor pressure contributing to sublimation and snowmelt in the model. Snow processes including SWE are modeled separately for a mosaic of elevation bands and vegetation types in each grid cell. Note that when solving for a subgrid tile of certain vegetation type and elevation band, VIC assumes that any snow fully covers that tile.

For this study, a grid layout at $1 / 8^{\circ}$ intervals (roughly $12 \mathrm{~km}$ on a side) were set up over the E-T basin. For each grid cell, the VIC model was run in energy balance mode, which solves the complete water balance but also minimizes surface energy balance errors. The surface energy balance is closed through an iterative process, which attempts to find a surface temperature that adjusts surface energy fluxes so that they balance the incoming solar and longwave radiation fluxes. Although computationally more expensive, this mode simulates the surface energy fluxes that are important to understanding the snow accumulation and ablation processes. Among many hydrologic quantities that the VIC model is able to simulate, only the daily SWE predictions for each grid cell both as individual elevation bands and as their areal averages were used as the primary output in this study.

To assess the effects of climate change on snow water availability, the VIC model was forced with gridded fields of minimum and maximum temperature, precipitation, wind speed, humidity, and solar radiation at sub-daily time steps. To establish the baseline snow dynamics in the basin, minimum and maximum temperature, precipitation, solar radiation, wind speed, and humidity on a $6 \mathrm{~h}$ time step were obtained from the National Centers for Environmental Prediction (NCEP) Global Reanalysis project data (Kalnay et al.,
1996) that were downscaled to $1 / 8^{\circ}$ resolution using a bilinear interpolator. To account for topographic effects on snow dynamics not captured at the coarse scale nature of the Reanalysis data, correction factors were applied to the temperature (lapsed by $6.1^{\circ} \mathrm{C} \mathrm{km}^{-1}$ ) and precipitation data following the Precipitation Regression on Independent Slopes Method (PRISM) algorithm (Daly et al., 1994). Even with these corrections, the derived forcing data did not exhibit large spatial variation within the mountainous portions of the basin (its effects are discussed in later sections). Nevertheless, the limitations in the forcing data may not have significant impacts because the snow accumulation and ablation processes in mountainous regions are controlled by the accumulated precipitation in snowpacks, and thus a lack of spatial variability in the input data may not be important (Hamlet et al., 2005). Further evidence that lack of spatial variability may not contribute to large model errors is shown by the VIC model's ability to capture the temporal and spatial patterns of snow covered areas and SWE (Fig. 4 through 6). Moreover, a comparison of the Reanalysis-derived climatic variables to those obtained from the National Climatic Data Center (NCDC) global summary of day reports for five meteorological stations located in the study area (NCDC, 2010) revealed a strong correlation for all forcing variables except precipitation (Table 1). The precipitation correlation was less than ideal, but may be attributable to an average $100 \mathrm{~mm}$ positive bias in the NCEP Reanalysis data.

In Table 1, the quantitative comparison between NCEP and station data was achieved using the correlation coefficient $(r)$, mean absolute error, (MAE), root mean square error (RMSE), and the index of agreement $(d)$ following Willmott (1981). The index of agreement is a measure of relative error in model estimates. It is a dimensionless number between 0.0 and 1.0 , where 0.0 describes complete disagreement between estimated and observed values, and 1.0 indicates that the simulated and observed values are identical. The index of agreement is included because the correlation coefficient $(r)$ cannot account for additive differences or differences in proportionality (Willmott, 1981). Nevertheless, $r$ (measure of covariability between observed and modeled values) and RMSE (measure of average difference between observed and modeled values) statistics are also included because they describe different components of model error indicated by $d$.

In its default configuration, the VIC model treats each grid cell to have a single elevation value (i.e. grid cells are flat). In mountainous areas where snow processes are an important part of the hydrological budget, the single elevation assumption can lead to inaccuracies in snow pack estimates. To overcome this issue, each grid cell in the E$\mathrm{T}$ basin was broken up into a total of six elevation bands (also called snow bands) and simulated individually. Along with the PRISM correction described above, VIC was used to lapse the grid cell average temperature, pressure, and precipitation to a more accurate local estimate, based on each 
Table 1. Statistics describing the strength of the relationship between three meteorological forcing variables measured at a single site (located at $37.96^{\circ} \mathrm{N}$ and $39.63^{\circ} \mathrm{E}$ ) and extracted from the NCEP dataset for the same location. The metrics used in comparison and their description and formulas are also provided.

\begin{tabular}{|c|c|c|c|c|c|c|c|c|c|c|}
\hline var & $N$ & $\bmod$ & obs & $S_{\text {mod }}$ & $S_{\text {obs }}$ & MAE & RMSE & $\mathrm{RMSE}_{\mathrm{S}}$ & $\mathrm{RMSE}_{U}$ & $d$ \\
\hline$T_{\max }$ & 13767 & 21.1 & 22.5 & 13.02 & 11.8 & 2.96 & 3.9 & 11.9 & 13.02 & 0.97 \\
\hline$T_{\min }$ & 13762 & 6.4 & 8.7 & 8.5 & 8.95 & 3.03 & 3.8 & 9.25 & 8.5 & 0.95 \\
\hline PREC & 13672 & 1.6 & 1.3 & 4.25 & 4.09 & 1.11 & 3.21 & 4.1 & 4.25 & 0.83 \\
\hline Statistic & \multicolumn{10}{|c|}{ Description } \\
\hline$N$ & \multicolumn{10}{|c|}{ number of samples } \\
\hline$\overline{\bmod }$ & \multicolumn{10}{|c|}{ mean modeled quantity $\left(\mathrm{mm} \mathrm{d}^{-1}\right.$ for precipitation and ${ }^{\circ} \mathrm{C}$ for temperature) } \\
\hline$\overline{\mathrm{obs}}$ & \multicolumn{10}{|c|}{ mean observed quantity ( $\mathrm{mm} \mathrm{d}^{-1}$ for precipitation and ${ }^{\circ} \mathrm{C}$ for temperature) } \\
\hline$S_{\text {mod }}$ & \multirow{2}{*}{\multicolumn{10}{|c|}{$\begin{array}{l}\text { standard deviation of modeled quantity }\left(\mathrm{mm} \mathrm{d}^{-1} \text { for precipitation and }{ }^{\circ} \mathrm{C} \text { for temperature) }\right. \\
\text { standard deviation of observed quantity }\left(\mathrm{mm} \mathrm{d}^{-1} \text { for precipitation and }{ }^{\circ} \mathrm{C} \text { for temperature) }\right.\end{array}$}} \\
\hline$S_{\mathrm{obs}}$ & & & & & & & & & & \\
\hline MAE & \multicolumn{10}{|c|}{ mean absolute error $\frac{1}{N} \sum_{i=1}^{n}\left|\bmod _{i}-\mathrm{obs}_{i}\right|$} \\
\hline RMSE & \multicolumn{10}{|c|}{ root mean squared error $\left[N^{-1} \sum_{i=1}^{n}\left(\bmod _{i}-\mathrm{obs}_{i}\right)^{2}\right]^{0.5}$} \\
\hline $\mathrm{RMSE}_{\mathrm{S}}$ & \multicolumn{10}{|c|}{ systematic RMSE $\left[N^{-1} \sum_{i=1}^{n}\left(\overline{\bmod }_{i}-\mathrm{obs}_{i}\right)^{2}\right]^{0.5}$} \\
\hline $\mathrm{RMSE}_{\mathrm{U}}$ & \multicolumn{10}{|c|}{ unsystematic RMSE $\left[N^{-1} \sum_{i=1}^{n}\left(\bmod _{i}-\overline{\bmod }_{i}\right)^{2}\right]^{0.5}$} \\
\hline \multirow[t]{2}{*}{$d$} & \multirow{2}{*}{\multicolumn{4}{|c|}{ index of agreement $d=1.0-$}} & \multicolumn{3}{|c|}{$\sum_{i=1}^{n}\left(\bmod _{i}-\mathrm{obs}_{i}\right)^{2}$} & & & \\
\hline & & & & & 1 & - & & & & \\
\hline
\end{tabular}

band's mean elevation value. As a result, VIC has the ability to predict snow-related variables by elevation band, although distribution within each band in non-spatial - i.e. the location of snow accumulation/ablation in the elevation band is not known. Aside from the simple climatic downscaling of the input climatic drivers and this correction, the VIC model does not introduce additional variability.

While this study primarily makes use of the detailed energy balance snow model described above (Cherkauer and Lettenmaier, 2003), the VIC model has been well validated with streamflow observations, particularly in the mountainous western US (Christensen et al., 2004; Hamlet et al., 2005; Maurer et al., 2002). The model has also been used extensively for streamflow forecasting applications (Hamlet and Lettenmaier, 1999; Wood et al., 2002) and for climate change assessments (Lettenmaier et al., 1999; Christensen et al., 2004; Hamlet and Lettenmaier, 1999; Payne et al., 2004; Snover et al., 2003).

\subsection{Climate change scenarios}

The climatic conditions used to represent a changing climate were constructed from the output of 13 Global Circulation Models (GCMs) obtained from the Coupled Model Intercomparison Project phase 3 (CMIP3) of the World Cli-
Table 2. List of GCMs and relevant references used in this study.

\begin{tabular}{lll}
\hline Model & Origin & Reference \\
\hline BCCR-BCM2.0 & Norway & Déqué et al. (1994) \\
CCMA_CGCM3.1 (T63) & Canada & Scinocca et al. (2008) \\
CNRM_CM3 & France & Salas-Mélia et al. (2005) \\
CSIRO_Mk3.5 & Australia & Gordon et al. (2002) \\
GFDL_CM2.1 & USA & Delworth et al. (2006) \\
GISS_ER & USA & Russell et al. (2000) \\
INM_CM3.0 & Russia & Diansky and Volodin (2002) \\
IPSL_CM4 & France & IPSL (2005) \\
MIROC3.2(med res) & Japan & K-1 model developers (2004) \\
MPI_ECHAM5 & Germany & Jungclaus et al. (2006) \\
MRI_CDCM2.3.2 & Japan & Yukimoto et al. (2001) \\
NCAR_CCSM3 & USA & Collins et al. (2006) \\
UKMO_HadCM3 & UK & Gordon et al. (2000) \\
\hline
\end{tabular}

mate Research Program (WCRP) (Meehl et al., 2007) (Table 2). Variables for the VIC model were extracted from each model by selecting the grid boxes most closely aligned with the study area. Note that the selected grid boxes occupy slightly different areas and locations between models due to different projection characteristics of each model's grid layout. Monthly data from the control and the perturbed 
(i.e. climate change) integrations of each model run were used to calculate the anomalies that were then applied to the observed subdaily baseline. The anomalies included monthly changes in precipitation intensity (in relative units), changes in the duration of wet and dry spells, changes in monthly temperature means (in absolute terms), and changes in monthly mean radiation (in absolute terms). Using these various datasets, the observed (i.e. baseline) data were adjusted to reflect each model's climate change predictions at monthly integrations, assuming stationarity in sub-monthly variability. Using monthly deviations from baseline observations, five years of synthetic sub-daily weather data were generated under a series of future climate scenarios. For the climate change impact assessment only two time periods were considered: 2045-2055 (2050s) and 2085-2095 (2090s) while the period between 1961-1990 represented the baseline conditions. For emission scenarios, two storylines were selected from the Special Report on Emission Scenarios (SRES) (IPCC, 2000): (1) the low-impact (B1) and (2) highimpact (A2) development scenario. Each storyline describes a different world evolving through the 21 st century and leads to different greenhouse gas emission trajectories driven by demographic, economic, technological, and land-use forces. The B1 scenario describes a convergent world (where developing and developed nations converge) with rapid changes in economic structures, reductions in the intensity resource use and the introduction of clean technologies. The emphasis is on global solutions to bring about economic, social, and environmental sustainability, including improving equity, but without additional climate change policies. The A2 storyline, in contrast, describes a differentiated world. Economic development is primarily regional, and technological changes are more fragmented in a world of self-reliance and continuously increasing population.

\subsubsection{Model calibration and validation}

The VIC model was validated for snow covered areas in the northern mountainous part of the E-T basin using multi-year satellite observations. The VIC model was run over the entire basin at $1 / 8^{\circ}$ spatial resolution and the results were compared to MODerate Resolution Imaging Spectroradiometer (MODIS) Terra Snow Cover 8-Day composited L3 Global 0.05Deg CMG (MOD10C2) data (Hall et al., 2002) for the entire basin. This comparison was made for four time periods in January 2001.

To validate the SWE output from the VIC model, two different observed datasets were used. The first dataset contained SWE observations obtained from the Directorate of Turkish Electrical Works snow observations book (EIEI, 2007). These observations are obtained roughly one time per month in mountainous areas of the country and include snow cover, depth, density and SWE. For the purposes of this study, data acquired at the station 21K07 (located at $38.93^{\circ} \mathrm{N}$ and $40.24^{\circ} \mathrm{E}$ ) were used. The statistics describing the strength of the relationship between observed and modeled values are given in Table 3.

The second comparison involved the use of remotely sensed observations. More specifically, VIC output from an additional single run at a site located in the headwaters of the Euphrates river in southeastern Turkey (centered at $40.5^{\circ} \mathrm{E}$ longitude, $38.5^{\circ} \mathrm{N}$ latitude) were compared to SWE data from the 8-day blended Special Sensor Microwave Imager (SSM/I) and the MODIS snow cover remote sensing product (Brodzik et al., 2007). The SWE dataset was derived from the SSM/I Pathfinder daily brightness temperatures. This dataset was enhanced by the MODIS snow cover area product derived from the MODIS/Terra Snow Cover 8-Day L3 Global 0.05Deg CMG (MOD10C2) data, regridded to the EASE-Grid. While spatially coarse, these remote sensingbased SWE datasets provide a first-order approximation of seasonal and interannual changes in SWE.

The final form of model evaluation was made by comparing modeled runoff generated by VIC's routing model against the observed runoff data obtained from the Directorate of Electrical Works monthly runoff book series (EIEI, 2008). We used data obtained from the Logmar station (located at $38.52^{\circ} \mathrm{N}$ and $39.49^{\circ} \mathrm{E}$ ) at a monthly time step between 1994 and 2004. The quality of fit between modeled and observed discharge was obtained by Nash-Sutcliffe model efficiency coefficient commonly used to assess the predictive power of models (Nash and Sutcliffe, 1970).

\section{Results}

\subsection{Expected changes in temperature and precipitation}

The deviations from baseline climatic conditions of the 20th century (1961-1990) predicted by 13 climate models under two climate change scenarios (A2, B1) for two time periods are provided as a temperature-precipitation cross-plot in Fig. 3. The temperature change was computed as the absolute difference (in ${ }^{\circ} \mathrm{C}$ ) between the baseline conditions and the climate change scenarios, thus positive values indicate increases in air temperature. The precipitation change was computed as the relative change from baseline conditions; negative numbers indicate a reduction in precipitation from the baseline.

In the future climate, the mean cold season air temperatures show a consistent pattern of increase under all model/scenario/year combinations. The amount of increase ranges from $0.7^{\circ} \mathrm{C}$ under the SRES B1 scenario in 2050 to greater than $5{ }^{\circ} \mathrm{C}$ under the SRES A2 scenario at the end of the 21 st century. All models also suggest consistent increases from 2050 to 2090, regardless of the emission scenario.

With respect to precipitation, most models suggest various levels of reduction - from 5 to 45 percent - under all scenarios and all time periods. A few models suggest slight increases in precipitation (up to 20 percent by one model), 




Fig. 4. Comparison of single day SWE observations to modeled quantities at a location in northern part of the E-T basin. The site is located at $\left(38.92^{\circ} \mathrm{N}\right.$ and $\left.40.25^{\circ} \mathrm{E}\right)$ and includes once-per-month observations. Sample dates of observed data are provided for reference.

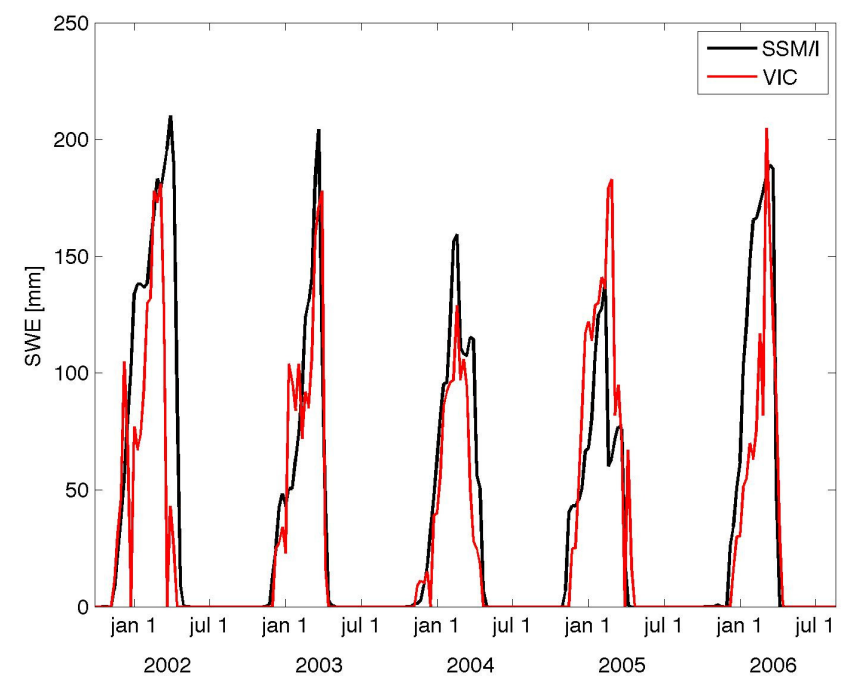

Fig. 5. A comparison of modeled (red) and observed (black) SWE at a location in southeastern Turkey $\left(40.5^{\circ} \mathrm{E}\right.$ longitude, $38.5^{\circ} \mathrm{N}$ latitude) within the Euphrates-Tigris basin for 2001-2006. The observed data are extracted from the 8-day blended Special Sensor Microwave Imager (SSM/I) data (Brodzik et al., 2007).

correspondence between the VIC model and the SSM/I observations for the timing of accumulation, maximum, and ablation of snow. The figure also points to interesting dynamics of SWE in the basin. First, snow accumulation begins in November of each year, gradually increases to a maximum in late March-early April, with a subsequent sharp decline into the summer season. Another important observation from

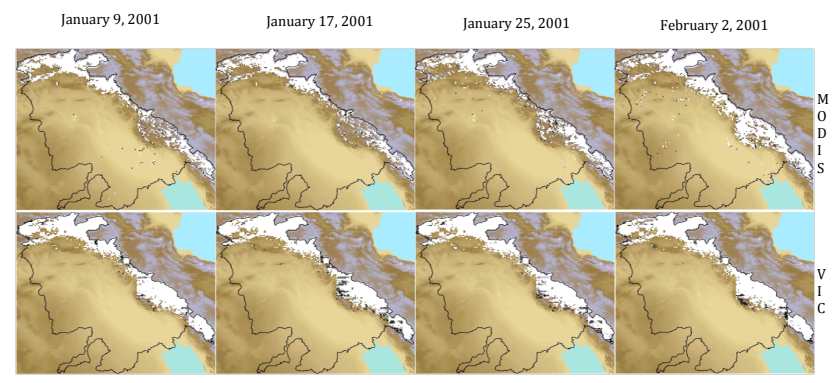

Fig. 6. Comparison of observed (top) and simulated (bottom) snow covered areas in the Euphrates-Tigris basin across different periods in winter 2001. Snow cover is indicated in white against the colorcoded topography of the basin. Observations in the top row were extracted from Terra MODIS 8-day snow cover product (MOD10C2) at $0.05^{\circ}$ spatial resolution, while the simulated results of the bottom row were produced in this research using the VIC model. More details on the MODIS snow cover product can be found in Hall et al. (2002). Each date at the top indicate the beginning date of the 8 -day compositing period.

Fig. 4 is the interannual variability of SWE. Both the modeled and remote sensing results had larger maximum SWE values (around $200 \mathrm{~mm}$ ) in years 2001, 2002, and $2006 \mathrm{had}$ than 2004 and 2005. Thus, while 2002 and 2003 are large snow accumulation years (and therefore larger SWE), 2004 and 2005 appear to be drier years with much less accumulation. It is interesting to note that both the VIC model and the satellite observations capture this variability quite well.

Further assessment of the VIC model performance was made by visually comparing modeled snow covered areas to satellite observations of snow cover from the MODIS sensor (Fig. 6). The map comparison between satellite-observed and modeled snow area data for four dates in January 2001 indicate a noticeable agreement. Even though VIC predicted a larger area covered by snow on each date, especially in the eastern mountainous zone of the basin, the general pattern of snow cover accumulating in the arc-shaped northern and eastern portions of the basin is remarkably similar between the two data sets. One reason for the larger area snow accumulation in VIC simulations is the coarse nature of the gridded weather data that smooth over the fine scale topographic variation present in the MODIS data.

Comparison of modeled discharge to observed quantities at a location in the northeastern portion of the basin further shows a notable correlation, especially in the timing of peak flows that are indicative of timing of snowmelt (Fig. 7). The modeled discharge data were obtained by routing VIC surface and baseflow predictions through the routing model of Lohmann et al. (1996). The quality of the match between the observed and modeled discharge determined by the NashSutcliffe coefficient of 0.5 is moderate although the timing of peak flows is matched nicely, indicating that VIC is able to simulate the accumulation and melting of snow in acceptable form. 


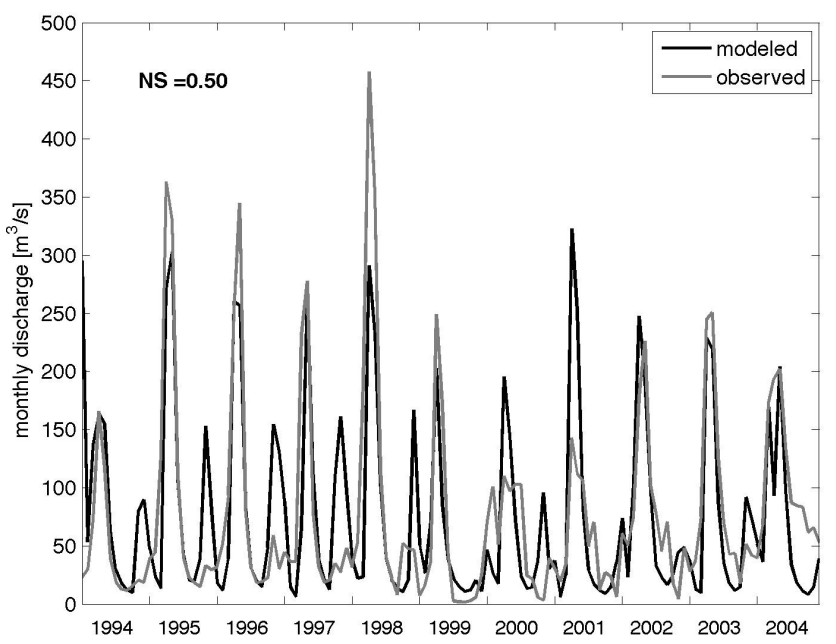

Fig. 7. Comparison of monthly observed and modeled discharge at the Logmar station (located at $38.51^{\circ} \mathrm{N}$ and $39.49^{\circ} \mathrm{E}$ ). While the absolute value flow is less than ideal in some cases, VIC model captures the timing of peak flow quite well. Nash-Sutcliffe (NS) statistic is also provided to show the strength of correlation.

\subsection{Changes in SWE for each GCM model outputs}

The changes in SWE across 12 of the 13 models are given in Fig. 8 where in each panel, deviations from the baseline conditions are depicted as a relative change in months defining the cold season. Note that even though the month of April is not generally considered part of the cold season in many northern hemisphere studies, it was included in the current study due to its importance for snow ablation and melting. Also shown with text in the figure are the largest absolute changes in SWE (in $\mathrm{mm}$ ) for the month in question. These absolute values reflect the averaged largest single day changes in SWE in each month. The direction of and magnitude of these absolute changes must be interpreted in the context of relative changes shown in the y-axis.

Overall, the following patterns emerge from Fig. 8. First, almost all models predict a decline in SWE in the DecemberJanuary period. However, there are fewer models predicting a decline in SWE in the March-April period, indicating that the reliability in predicting a decline in SWE is reduced when moving from the December-January period to the MarchApril period. Second, there is considerable variability across the models. For example, the GFDL model predicts a strong negative change in SWE across all months, years, and emission scenarios, while the CNNM model predicts a weak negative response in SWE under a changing climate (less than 40 percent). In some cases, the models even predict a positive response. Across all models, the predicted increase, although rare, occurs in the spring during the normal thawing period in 10 out of 13 models. This represents a shift in the timing of snow accumulation, moving from the December-February period to the March-April period. Another interesting obser- vation concerning the increase in SWE with climate change is that it occurs more often under the B1 than the A2 scenario, and more frequently in the middle of the 21 st century (2050s) than in the later period (2090s).

There are notable exceptions to these general trends. For instance, the NCAR model does not fit this description; results from this model suggest a steady increase in SWE availability under the aggressive A2 scenario at the end of the 21st century (although this increase occurs more in April than in January). Several other models, including the IPSL and the MIROC models, also show similar trends, but to a lesser extent. However, all of these exceptions tend to occur in the spring rather than during the cold season under changing climatic conditions.

Absolute changes in SWE as depicted by the number below bars representing each month also tell a similar story but in different context. First, the absolute magnitude of SWE changes is highly variable, ranging from less than 20 to over $230 \mathrm{~mm}$. When placed in context of available snow water at the peak snow accumulation period (as much as $400 \mathrm{~mm}$ ), these absolute changes reflect 10 to 60 percent of the available snow water. Second, the largest changes (and the most variation across models) occur in April followed by March. The timing of these largest changes in the spring are in contrast with the large relative changes that occur in the winter period. Although these largest changes do not necessarily reflect the largest relative changes, they indicate the importance of climate change for accumulation (winter) and decay (spring) of SWE.

Given the model-derived variability in predicting climate variables that are important for snow accumulation, the question arises as to which models or strategies should be used to distill information of use to stake-holders. One common approach is simply to average all models. This approach, commonly referred to as a multi-model ensemble, dilutes models that provide poor outcomes with those that do a good job in simulating a region (Lambert and Boer, 2001; Pierce et al., 2009). Using this approach, a new multi-model ensemble climate forcing dataset was generated for input to the VIC model. By averaging the outcomes of all climate models, the ensemble results suggest that SWE could decline as much as 40 percent under all emission scenarios, all time periods and all months considered in this study (Fig. 9). Of greater interest, however, is the gradual decline in the reduction in SWE from December (largest decrease) to April (smallest decrease). These findings suggest that the amount of snow that help build SWE during the cold season could gradually lessen, leaving little or no snowmelt generated flow in the spring. As with individual models, the absolute changes increase from winter to spring.

Rather than average the negative or positive changes as in the ensemble approach, it is possible to explore the frequency with which the models predict positive or negative changes by month. In Fig. 10, the number of times an increase or decrease was predicted by a model is plotted, where the length 

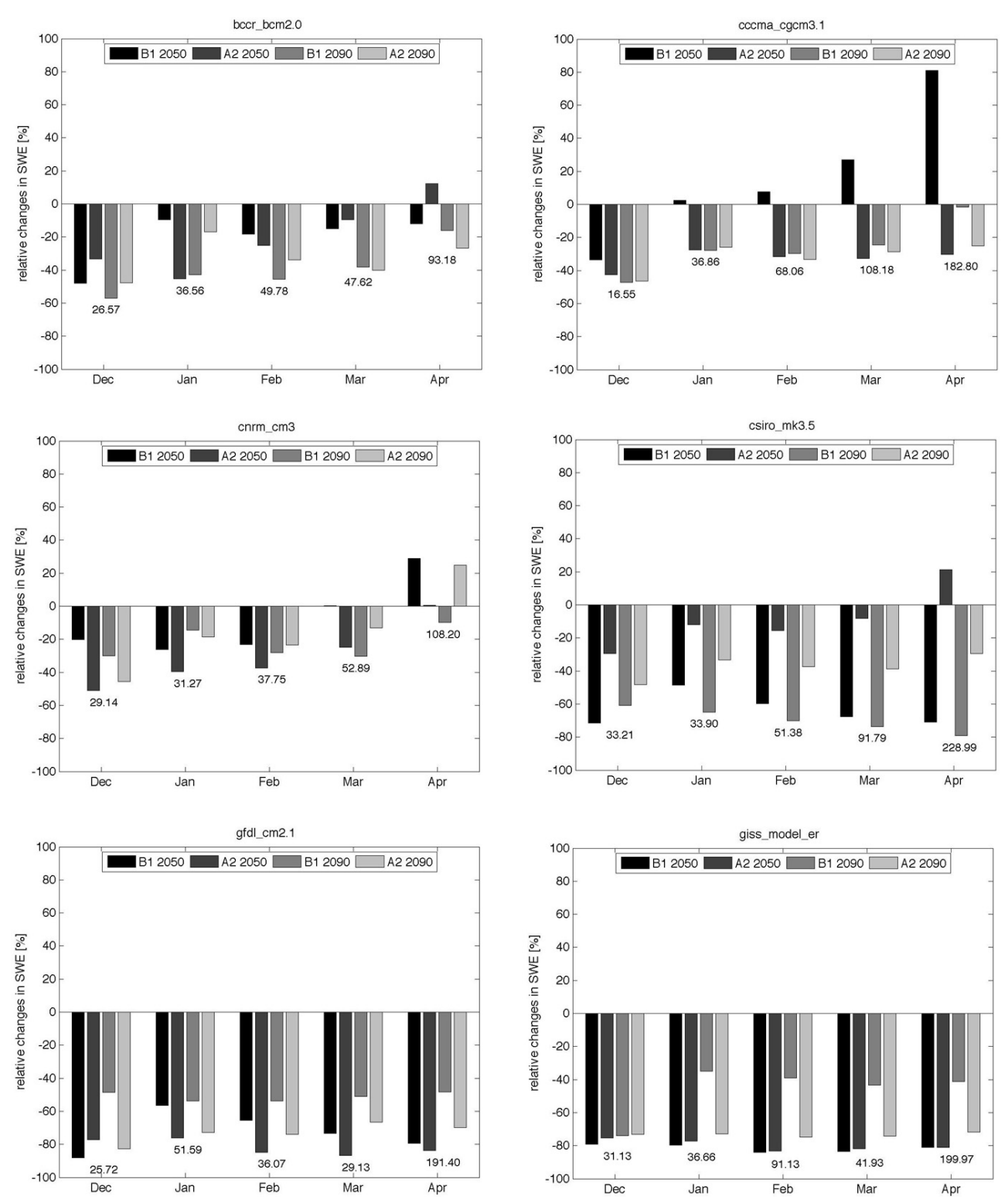

Fig. 8. Changes in basin-averaged SWE relative to baseline conditions (1961-1990) predicted by 12 GCMs for the cold season (DJFMA). Negative values indicate a reduction and positive values indicate an increase in SWE relative to baseline conditions. Also shown are the maximum averaged absolute changes in SWE (in units of $\mathrm{mm} / \mathrm{month}$ ). The sign of the absolute change must be interpreted with the direction of relative change on the y-axis. Note that only 12 out of 13 models used in the study are shown.

of each bar is equal to 13 , representing the total number of models used. The first finding from this plot is that all models indicate a clear decline in December under changing climate conditions. Moreover, many of the models predict a decline in SWE January through March. Yet, only half the models predict an increase while the other half predict a decrease in April, and this result is consistent across all emission scenarios and time periods. This lack of consensus among models in April is mostly due to lack of snow in this period. In other words, the amount of reduction on an already small snow quantity in the spring is lost between model variability. In the winter period however, all models do predict snow availability but simply less of it under a changing climate.

Finally, Fig. 11 shows the changes in modeled SWE across elevation zones (or bands) for four scenario/time combinations. The elevation bands are given at $250 \mathrm{~m}$ increments on the $y$-axis while the $x$-axis depicts the departure of SWE from the baseline conditions in relative terms. The results reveal that the largest changes (greater than 50 percent) occur in the lower elevation bands (under $500 \mathrm{~m}$ ) and as altitude increases, the reduction in SWE diminishes exponentially to a minimum value of about 10 percent. Above $2000 \mathrm{~m}$, the 

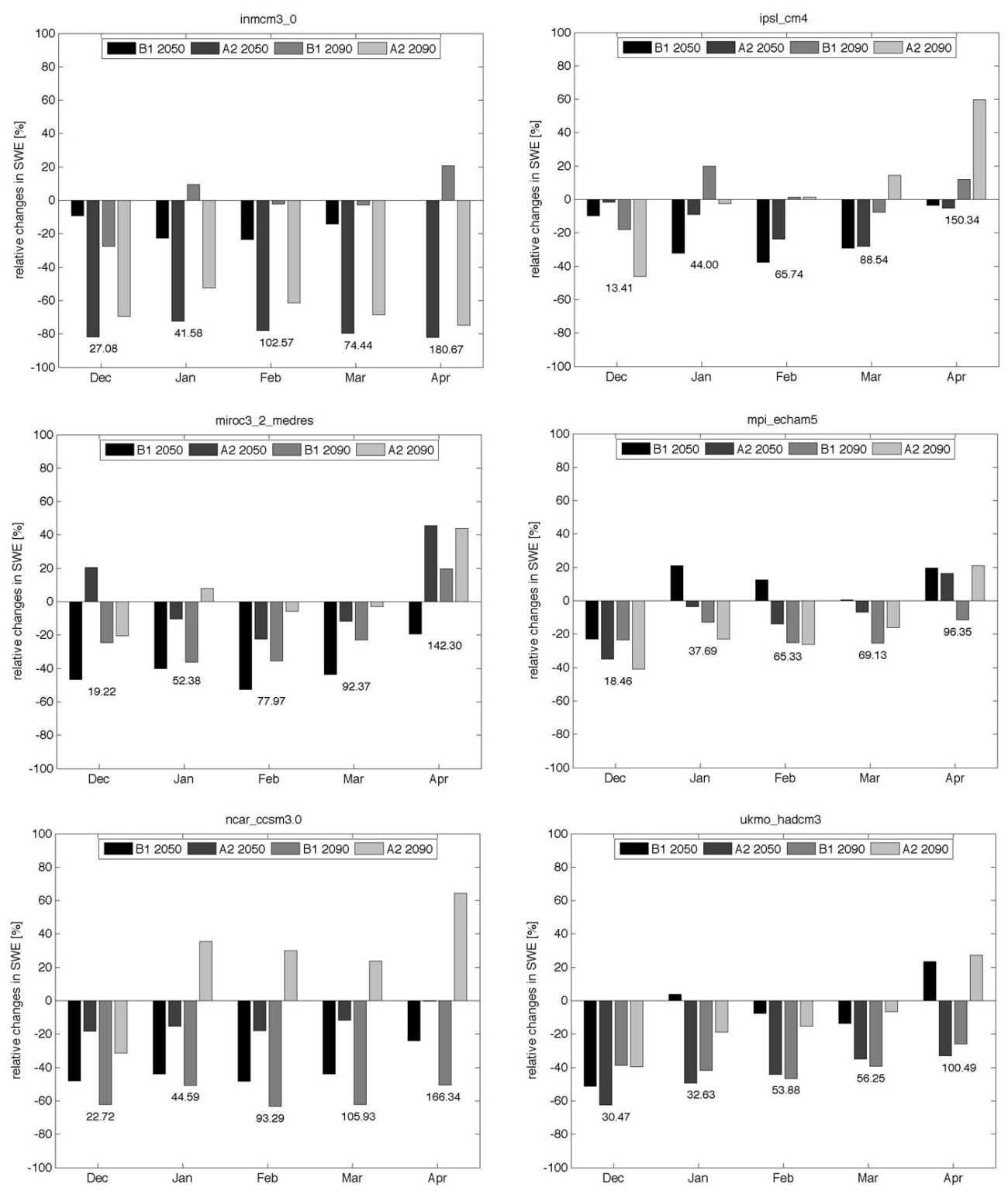

Fig. 8. Continued.

predicted decline in SWE is constant with a mean value of 10 percent. However, slight positive bias in VIC-simulated snow area and SWE amounts in lower elevations suggests that the magnitude of change in lower elevations must be viewed with caution. This is also corroborated by lack of model consensus in April, which affect lower elevations first. These findings suggest that as the climate warms and precipitation declines, lower elevation zones could experience a more rapid reduction in snow accumulation than the higher elevation zones of the basin but these results are as good as the quality of the model predictions in the lower areas.

\section{Discussion}

In this research, the effects of climate change on the amount of water stored in snowpack in the mountains of the Euphrates-Tigris river basin were assessed using the VIC macroscale hydrological model linked to climate model results. Inevitably, the approach adopted in this study has several limitations. With respect to the climate change predictions, this study only considered the averages of the regional climate system, but did not assess changes in its variability. While the approach taken here involving the perturbation of observed climate allows for some random variation in day-to-day weather events, the true variability, including climatic extremes, is not captured. Work on the sensitivity of 


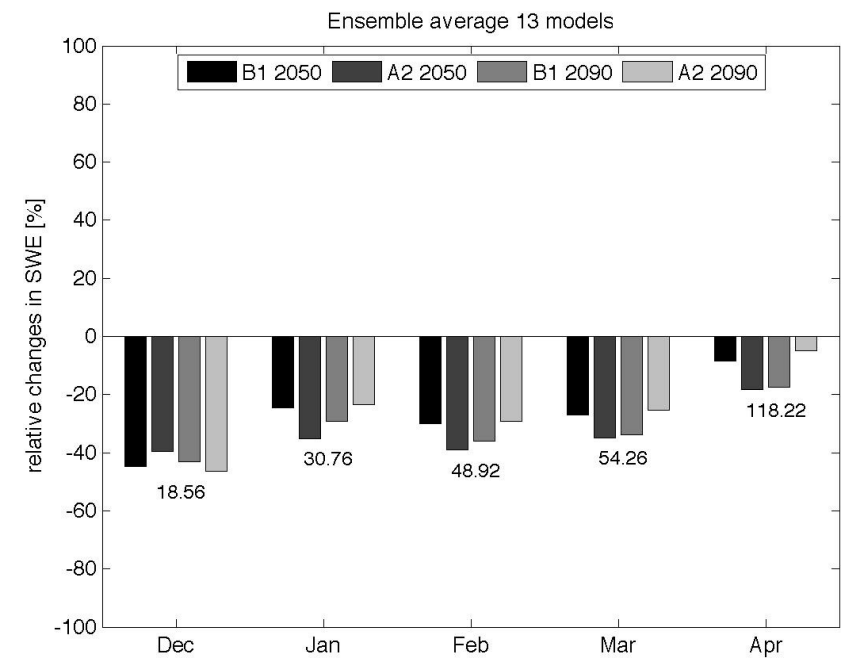

Fig. 9. Changes in basin-averaged SWE relative to baseline conditions (1961-1990) predicted by multi-model ensemble outputs for the cold season (DJFMA). Negative values indicate a reduction and positive values indicates an increase in SWE relative to baseline conditions.

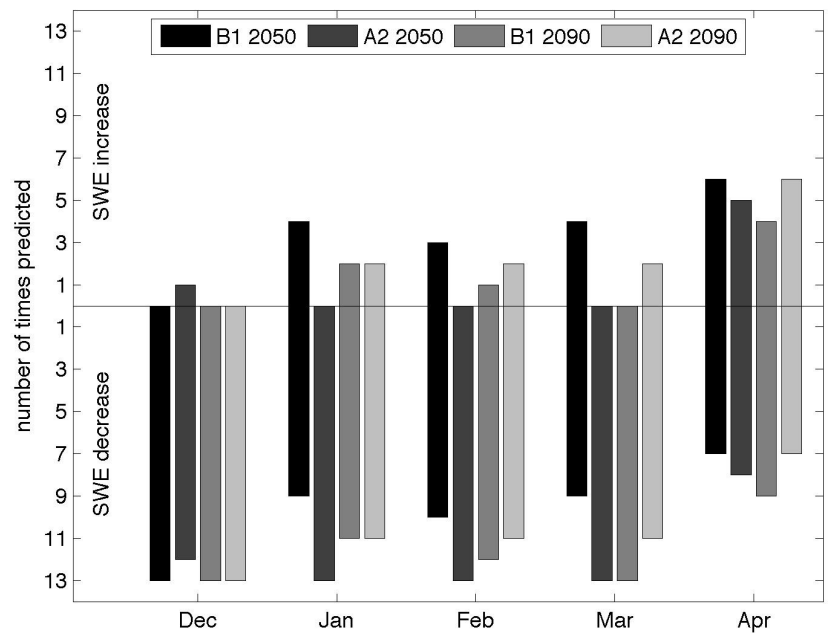

Fig. 10. Number of models that predicted an increase (the upper half) and a decrease (the lower half) in SWE relative to baseline conditions for each month/scenario/period combination. In general, more models predict a decrease in SWE, especially in the December-March period when snow accumulation is greatest.

snowpack to changes in the frequency and magnitude of extreme weather events suggests long term droughts and cold spells could have important consequences for winter water storage (see, e.g. Mote, 2006). Thus, the "average" predicted changes in future snowpack presented in this study may under- or over-estimate future water yields from snow melt in the basin. In addition, studies such as this could further benefit from probabilistic modeling of uncertainty associated with climate.

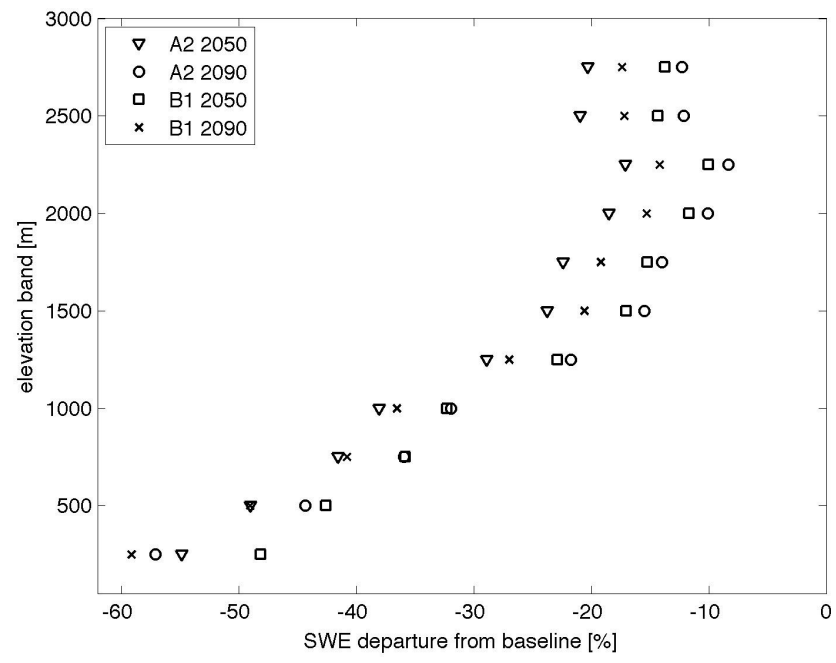

Fig. 11. Changes in modeled SWE across elevation zones for four scenario/time combinations. Each marker plot represents the average VIC SWE outcome from the 13 GCM climate forcing data.

Another climate model-related limitation of this study is the application of GCM-predicted anomalies to observed temperature and precipitation. While it is possible to downscale large GCM grids statistically or dynamically so that the spatial variability across a study area can be examined, this was not done in this study. There is evidence to suggest that it is preferable to apply the native GCM-predicted climate anomalies to observed data in order to construct climate scenarios rather than derive them directly from the regional climate model simulations or by statistical downscaling (e.g. Arnell et al., 2003; Salathé et al., 2007)

The comparison of future climatic conditions from 13 GCMs provides several important observations. First, there is significant variation in future conditions across the different models, even though all models were forced with the same emissions scenarios. Second, the models respond differently to emission scenarios in different time periods. Third, the model results suggest that variability in precipitation estimates is much greater than the variability of estimates for temperature. For example, the NCAR model predicts a 20 percent increase in 2050, while the CSIRO model suggests a greater than 40 percent decrease in rainfall in 2050 under the same emissions scenario. Temperature, on the other hand, has an expected pattern of change across models, generally increasing into the 21 st century across successive periods but with variability in the amount of increase. For example, the variation in temperature increase from less than $1{ }^{\circ} \mathrm{C}$ with the MIROC3 model to around $3{ }^{\circ} \mathrm{C}$ with the IPSL model. This variation across models is one reason for using the multi-model ensemble approach adopted here. This type of multi-model ensemble approach is already in use in global studies that examine the mean state of a given climate and has also been found to be superior to any individual model output 
in studies at a regional scale (Pierce et al., 2009). Research suggests that this occurs as a result of errors in individual models cancelling out one another. In the fourth assessment report, IPCC points out discrepancies among models and suggests the use of multiple models for any impact assessment (IPCC, 2007b). In the present study, both the individual model and the multi-model ensemble average approach were utilized, unlike previous studies that investigated the effects of climate change on water yield in the E-T basin.

Another limitation of this study is concerned with lack of subgrid variability in snow processes in the VIC model. There is evidence to suggest that, from a hydrological perspective, the subgrid snow-depth distribution is an important quantity to include within macro scale models (e.g. Leung and Qian, 2003; Liston, 2004). This is because subgrid snow distribution is the critical first-order influence on snow-cover depletion during snowmelt, since the spatiallyvariable subgrid SWE distribution is largely responsible for the patchy mosaic of snow covered areas. In the current research, the within-grid variability of snow covered area and associated SWE is represented as elevation bands only and may be under- or over-estimated. In addition to elevation, the true subgrid snow distribution is also strongly influenced by spatial variations in snow-canopy interactions, snow redistribution by wind, and orographic precipitation (Liston, 2004).

The results presented in this research have important implications for the future of water availability in the region; they may perhaps pave the way for adaptation options. A significant decline in water stored in snowpack is likely to depress overall production volumes and the timing of peak flow, thus affecting reservoir storage for power generation and warm season irrigation. Currently, there are more than 20 dams and reservoirs with modest to large storage capacities in the basin. The expected snowpack reduction along with the shift of runoff peak from spring to winter due to climate warming is likely to have important effects on power generation and revenues in Turkey and Iraq. Since all of the existing capacity was designed under contemporary climate conditions to take advantage of snowpack as a natural reservoir, the adaptability of the storage structures is in question when climate warming is considered. Expansion of storage capacity, and to a lesser extent generation capacity, may increase water availability, although such expansions might be hugely cost prohibitive. As a result, countermeasures for water shortages could become much more difficult.

In addition to its impacts on water management, climate change introduces another element of uncertainty about future water resource management in the E-T basin. Water resources of the region are heavily managed and all aspects of water usage are politically charged. The allocation of water between the three countries of the E-T basin has led to at least fifteen conflicts in the past four decades (Gleick, 2009). While another conflict may not be likely in the short-term (Beaumont, 1998), the future reduction of snow and its as- sociated runoff may be enough for countries in the basin to risk conflict (Beaumont, 1998). Therefore, implementation of adaptation measures, such as water conservation, use of markets to allocate water, and the application of appropriate management practices will play an important role in determining the impacts of climate change on water resources.

\section{Conclusions}

Water stored in seasonal snowpack in the crescent-shaped mountains of the Euphrates-Tigris basin is an extremely important resource for the countries of the region. Using a comprehensive assessment involving 13 general circulation models, two greenhouse gas emission scenarios, and two time periods, the results of this research suggest that climate change has the potential to severely reduce (between 10 to 60 percent) the amount of this water source and place increased stress on the water-dependant societies of the region. These findings are verified not only by individual GCM outcomes but also by the outputs of a multi-model ensemble developed to reduce inter-model variation. The results also reveal that the largest changes (greater than 50 percent) in SWE occur in the lower elevation bands (under $500 \mathrm{~m}$ ) and as altitude increases, the reduction in SWE will diminish exponentially suggesting a more rapid reduction in snow accumulation in the lower zones of the basin, although these results are less certain than basin averaged changes in snow water availability. While there are uncertainties associated with both the climate model outputs and outputs provided by the VIC model, the results of this investigation could have important implications in the development of strategies to address the climate change problem in a region already fraught with water-related conflicts.

Acknowledgements. This research is partially funded by a NASA Application Science Program grant number NNX08AM69G awarded to the author. Early edits and suggestions of George Allez significantly improved the readability of this document. The author also thanks to Annemarie Schneider for her comments on an early version of this document that made it more clear and succinct. The comments of three anonymous reviewers substantially improved the content and the readability of this manuscript. Finally, the author acknowledges the modeling groups, the Program for Climate Model Diagnosis and Intercomparison (PCMDI) and the WCRP's Working Group on Coupled Modelling (WGCM) for their roles in making the WCRP CMIP3 multi-model dataset available. Support for that dataset was provided by the Office of Science, US Department of Energy.

Edited by: J. Liu 


\section{References}

Beaumont, P.: Restructuring of Water Usage in the Tigris-Euphrates Basin: The Impact of Modern Water Management Projects, in: Transformation of Middle Eastern Natural, Environments: Legacies and Lessons, edited by: Coppock, J. and Miller, J. A., Yale University, New Haven, 1998.

Beniston, M., Keller, F., and Goyette, S.: Snowpack in the Swiss Alps under changing climatic conditions: an empirical approach for climate impacts studies, Theor. Appl. Climatol., 74, 19-31, 2003.

Brodzik, M. J., Armstrong, R. L., and Savoie, M: Global EASEGrid 8-day Blended SSM/I and MODIS Snow Cover, (20012006), Boulder, Colorado USA: National Snow and Ice Data Center, Digital media, 2007.

Christensen, N. S., Wood, A. W., Voisin, N., Lettenmaier, D. P., and Palmer, R. N.: Effects of climate change on the hydrology and water resources of the Colorado River Basin, Clim. Change, 62, 337-363, 2004.

Christensen, N. S. and Lettenmaier, D. P.: A multimodel ensemble approach to assessment of climate change impacts on the hydrology and water resources of the Colorado River Basin, Hydrol. Earth Syst. Sci., 11, 1417-1434, doi:10.5194/hess-11-14172007, 2007.

Cherkauer, K. A. and Lettenmaier, D. P.: Simulation of spatial variability in snow and frozen soil. J. Geophys. Res., 108(D22), 8858, doi:10.1029/2003JD003575, 2003.

Collins, W. D., Blackmon, M. L., Bonan, G. B., Hack, J. J., Henderson, T. B., Kiehl, J. T., Large, W. G., McKenna, D. S., Bitz, C. M., Bretherton, C. S., Carton, J. A., Chang, P., Doney, S. C., Santer, B. D., and Smith, R. D.: The Community Climate System Model Version 3 (CCSM3), J. Climate, 19, 2122-2143, 2006.

Delworth, T. L., Broccoli, A. J., Rosati, A., Stouffer, R. J., Balaji, V., Beesley, J. A., Cooke, W. F., Dixon, K. W., Dunne, J., Dunne, K. A., Durachta, J. W., Findell, K. L., Ginoux, P., Gnanadesikan, A., Gordon, C. T., Griffies, S. M., Gudgel, R., Harrison, M. J., Held, I. M., Hemler, R. S., Horowitz, L. W., Klein, S. A., Knutson, T. R., Kushner, P. J., Langenhorst, A. R., Lee, H. C., Lin, S. J., Lu, J., Malyshev, S. L., Milly, P. C. D., Ramaswamy, V., Russell, J., Schwarzkopf, M. D., Shevliakova, E., Sirutis, J. J., Spelman, M. J., Stern, W. F., Winton, M., Wittenberg, A. T., Wyman, B., Zeng, F., and Zhang, R.: GFDL's CM2 global coupled climate models. Part I: Formulation and simulation characteristics, J. Climate, 19, 643-674, 2006.

Déqué, M., Dreveton, C., Braun, A., and Cariolle, D.: The ARPEGE/IFS atmosphere model : A contribution to the French community climate modeling, Clim. Dynam., 10, 249-266, 1994.

Diansky, N. A. and Volodin, E. M.: Simulation of present-day climate with a coupled Atmosphere-ocean general circulation model, Izv. Atmos. Ocean. Phys. (Engl. Transl.), 38, 732-747, 2002.

EIEI: Snow Observations (1966-2005), Hydrologic Research Unit, General Directorate of Electrical Works, Ankara, Turkey, 491 pp., January, 2007.

EIEI: Monthly Flow Averages of Turkish Rivers (1935-2005), Hydrologic Research Unit, General Directorate of Electrical Works, Ankara, Turkey, 740 p., September, 2008.

Evans, J. P.: 21st century climate change in the Middle East, Clim. Change, 92, 417-432, doi:10.1007/s10584-008-9438-5, 2009.
Gleick, P. H.: Water: The potential consequences of climate variability and change for the water resources of the United States. Report of the Water Sector Assessment Team of the National Assessment of the Potential Consequences of Climate Variability and Change, Pacific Institute for Studies in Development, Environment, and Security, Oakland, CA, 151 pp., 2000.

Gleick, P. H.: Water and conflict Chronology, in: The World's Water 2008-2009, Island Press, Washington, D. C., 151-194, 2009.

Gordon, C., Cooper, C. Senior, C. A., Banks, H. T., Gregory, J. M., Johns, T. C., Mitchell, J. F. B., and Wood, R. A.: The simulation of SST, sea ice extents and ocean heat transports in a version of the Hadley Centre coupled model without flux adjustments, Clim. Dynam., 16, 147-168, 2000.

Gordon, H. B., Rotstayn, L. D., McGregor, J. L., Dix, M. R., Kowalczyk, E.A., O'Farrell, S. P., Waterman, L. J., Hirst, A. C., Wilson,. G., Collier, M. A., Watterson, I. G., and Elliott, T. I.: The CSIRO Mk3 Climate System Model, CSIRO Atmospheric Research Technical Paper No. 60, CSIRO, Division of Atmospheric Research, Victoria, Australia, 130 pp., 2002.

Gruen, G. E.: Turkish waters: Source of regional conflict or catalyst for peace?, Water Air Soil Poll. 123, 565-579, 2000.

Hall, D. K., Riggs, G. A., Salomonson, V. V., DiGirolamo, N. E., and Bayr, K. J.: MODIS snow-cover products, Remote Sens. Environ., 83, 181-194, 2002.

Hamlet, A. F. and Lettenmaier, D. P.: Effects of Climate Change on Hydrology and Water Resources in the Columbia River Basin, J. Am. Water Resour. As., 35, 1597-1623, 1999.

Hamlet, A. F., Mote, P. W., Clark, M. P., and Lettenmaier, D. P.: Effects of temperature and precipitation variability on snowpack trends in the western United States, J. Climate, 18, 4545-4561, 2005.

IPCC: Special Report on Emission Scenarios, edited by: Nakicenovic, N. and Swart, R., Cambridge University Press, UK, 570 pp, 2000.

IPCC: Climate Change 2007: The Physical Science Basis, Contribution of Working Group I to the Fourth Assessment Report of the Intergovernmental Panel on Climate Change, edited by: Solomon, S., Qin, D., Manning, M., Chen, Z., Marquis, M., Averyt, K. B., Tignor M., and Miller, H. L., Cambridge University Press, Cambridge, United Kingdom and New York, NY, USA, 996 pp., 2007a.

IPCC: Climate Change 2007: Impacts, Adaptation, and Vulnerability, Contribution of Working Group II to the Fourth Assessment Report of the Intergovernmental Panel on Climate Change, edited by: Parry, M. L., Canziani, O. F., Palutikof, J. P., van der Linden, P. J., and Hanson, C. E., Cambridge University Press, Cambridge, United Kingdom, 1000 pp., 2007b.

IPSL: The new IPSL climate system model: IPSL-CM4', Institut Pierre Simon Laplace des Sciences de l'Environnement Global, Paris, France, 73 pp., 2005.

Jungclaus, J. H., Botzet, M., Haak, H., Keenlyside, N., Luo, J.J., Latif, M., Marotzke, J., Mikolajewicz, U., and Roeckner, E.: Ocean circulation and tropical variability in the AOGCM ECHAM5/MPI-OM, J. Climate, 19, 3952-3972, 2006.

Kalnay, E., Kanamitsu, M., Kistler, R., Collins, W., Deaven, D., Gandin, L., Iredell, M., Saha, S., White, G., Woollen, J., Zhu, Y., Leetmaa, A., Reynolds, R., Chelliah, M., Ebisuzaki, W., Higgins, W., Janowiak, J., Mo, K. C., Ropelewski, C., Wang, Jenne, R., and Joseph, D.: The NCEP/NCAR 40-Year Reanalysis 
Project, Bull. Am. Meteorol. Soc., 77, 437-471, 1996.

K-1 model developers: K-1 coupled model (MIROC) description, K-1 technical report, 1, edited by: Hasumi, H. and Emori, S., Center for Climate System Research, University of Tokyo, 34 pp., 2004.

Kitoh, A., Yatagai, A., and Alpert, P.: First super-highresolution model projection that the ancient "Fertile Crescent" will disappear in this century, Hydrol. Res. Lett., 2, 1-4, doi:10.3178/HRL.2.1, 2008.

Lambert, S. J. and Boer, G. J.: CMIP1 evaluation and intercomparison of coupled climate Models, Clim. Dynam., 17, 83106, 2001.

Lettenmaier, D. P., Wood, A. W., Palmer, R. N., Wood, E. F., and Stakhiv, E. Z.: Water resources implications of global warming: A US regional perspective, Clim. Change, 43, 537-579, 1999.

Leung, L. R. and Qian, Y.: The sensitivity of precipitation and snowpack simulations to model resolution via nesting in regions of complex terrain, J. Hydrometeorology, 4, 1025-1043, 2003.

Liang, X., Lettenmaier, D. P., Wood, E. F., and Burges, S. J.: A simple hydrologically based model of land surface water and energy fluxes for general circulation models, J. Geophys. Res., 99, 14415-14428, 1994.

Liston, G. E.: Representing subgrid snow cover heterogeneities in regional and global models, J. Climate, 17, 1381-1397, 2004.

Lohmann, D., Nolte-Holube, R., and Raschke, E.: A large-scale horizontal routing model to be coupled to land surface parameterization schemes, Tellus A, 48, 708-21, 1996.

McCabe, G. J. and Wolock, D. M.: General-circulation-model simulations of future snowpack in the western United States, J. Am. Water Resour. As., 35, 1473-1484, 1999.

McCabe G. J. and Wolock, D. M.: Recent declines in western US snowpack in the context of twentieth-century climate variability, Earth Interact., 13, 1-15, 2009.

Meehl, G. A., Covey, C., Delworth, T., Latif, M., McAvaney, B., Mitchell, J. F. B., Stouffer, R. J., and Taylor, K. E.: The WCRP CMIP3 multi-model dataset: A new era in climate change research, Bull. Am. Meteorol. Soc., 88, 1383-1394, 2007.

Milly, P. C. D., Dunne, K. A., and Vecchia, A. V.: Global patterns of trends in streamflow and water availability in a changing climate, Nature, 438, 347-350, 2005.

Mote, P. W., Hamlet, A. F., Clark, M. P., and Lettenmaier, D. P.: Declining mountain snowpack in western North America, Bull. Am. Meteorol. Soc., 86, 39-49, 2005.

Mote, P. W.: Climate-driven variability and trends in mountain snowpack in western North America, J. Climate, 19, 6209-6220, 2006.

Nash, J. E. and Sutcliffe, J. V.: River flow forecasting through conceptual models part I - A discussion of principles, J. Hydrol., 10(3), 282-290, 1970.
NCDC: Global Summary of day data product, available at: http: //www.ncdc.noaa.gov/cgi-bin/res40.pl?page=gsod.html (last access: March 2010), 2010.

New, M., Lister, D., Hulme, M., and Makin, I.: A high-resolution data set of surface climate over global land areas, Clim. Res., 21, 1-25, 2002.

Nijssen, B., Lettenmaier, D. P., Liang, X., Wetzel, S. W., and Wood, E. F.: Streamflow simulation for continental-scale river basins, Water Resour. Res., 33, 711-24, 1997.

Önol, B. and Semazzi, F. H. M.: Regionalization of Climate Change Simulations over the Eastern Mediterranean, J. Climate, 22, 1944-1961, doi:10.1175/2008JCLI1807.1, 2009.

Pierce, D. W., Barnett, T. P., Santer, B. D., and Gleckler, P. J.: Selecting global climate models for regional climate change studies, P. Natl. Acad. Sci. USA, 106, 8441-8446, 2009.

Russell, G. L., Miller, J. R., Rind, D., Ruedy, R. A., Schmidt, G. A., and Sheth, S.: Comparison of model and observed regional temperature changes during the past 40 years, J. Geophys. Res., 105, 14891-14898, 2000.

Salas-Mélia, D., Chauvin, F., Déqué, M., Douville, H., Gueremy, J. F., Marquet, P., Planton, S., Royer J. F., and Tyteca, S.: Description and validation of the CNRM-CM3 global coupled model, CNRM working note 103, available at: http://www.cnrm.meteo. fr/scenario2004/papercm3.pdf, 2005.

Salathé, E. P., Mote, P. W., and Wiley, M. W.: Review of scenario selection and downscaling methods for the assessment of climate change impacts on hydrology in the United States pacific northwest, Int. J. Climatol., 27, 1611-1621, doi:10.1002/joc.1540, 2007.

Scinocca, J. F., McFarlane, N. A., Lazare, M., Li, J., and Plummer, D.: Technical Note: The CCCma third generation AGCM and its extension into the middle atmosphere, Atmos. Chem. Phys., 8, 7055-7074, doi:10.5194/acp-8-7055-2008, 2008.

Storck, P.: Trees, snow and flooding: An investigation of forest canopy effects on snow accumulation and melt at the plot and watershed scales in the Pacific Northwest, Water Resources Series, Tech. Rep. 161, Department of Civil and Environmental Engineering, University of Washington, 176 pp., 2000.

Storck, P., Lettenmaier, D. P., and Bolton, S.: Measurement of snow interception and canopy effects on snow accumulation and melt in mountainous maritime climate, Oregon, USA, Water Resour. Res., 38, 1223-1238, 2002.

Willmott, C. J.: On the validation of models, Phys. Geogr. 2, 184194, 1981.

Yukimoto, S., Noda, A., Kitoh A., Sugi, M., Kitamura, Y., Hosaka, M., Shibata, K., Maeda, S., and Uchiyama, T.: The New Meteorological Research Institute Coupled GCM (MRI-CGCM2), Model climate and variability, Pap. Meteorol. Geophys., 51, 4788, 2001. 